\title{
APPLICATION OF SURVEYING AND MAPPING TECHNOLOGY IN DISEASE EXTRACTION AND ANALYSIS OF STONE MONUMENTS
}

\author{
Zheng. $\mathrm{Yu}^{1} \cdot 2 \cdot *$, Yungang. $\mathrm{Hu}^{1,2}$,Miaole.Hou ${ }^{1 \cdot 2}$ \\ ${ }^{1}$ School of Geomatics and Urban Spatial Informatics, Beijing University of Civil Engineering and Architecture, No.15 Yongyuan \\ Road, Daxing District, Beijing; 102616, China; yz18801430214@126.com(Z.Y.); huyungang@bucea.edu.cn (Y.H.); \\ houmiaole@bucea.edu.cn (M.H.) \\ ${ }^{2}$ Beijing Key Laboratory for Architectural Heritage Fine Reconstruction and Health Monitoring, No.15 Yongyuan Road, Daxing \\ District, Beijing; 102616, China
}

KEY WORDS: Stone monuments, Surveying and mapping technology, Preventive protection, Disease extraction, Disease analysis.

\begin{abstract}
:
With thousands of years of glorious history and culture, China, which is the origin of Chinese civilization has also survived with a magnificent amount of stone cultural heritage. Stone monuments are one of the most important components of Chinese monuments and contain a wealth of historical information by themselves. Due to the fact that some stone monuments and stone architectural elements are often exposed to the natural environment, they are subject to physical, biological, chemical and human damage over a long period of time, which leads to the formation of various kinds of damages. Therefore, it is an important issue to extract and analysis the diseases information effectively. In this paper, we were going to examine these issues in the context of existing surveying and mapping techniques.
\end{abstract}

\section{INTRODUCTION}

Stone monuments are widely distributed and numerous in China. It has great historical value, artistic value, and scientific value. Only in the aspect of protecting and using the representative grotto temples, relevant guidelines have been issued from the national level. However, the theory and method of stone monuments protection are still being explored (Huang, 2006; Plevoets, Van Cleempoel, 2001). From the basic concept (Maev et al., 2020), disease types and evaluation system of stone monuments protection (Wang, Huo, 2021), protection concept (De Wever et al., 2017), procedure method and material application (Huang, 2014), they all need to be further studied to construct a complete discipline system.

The extraction and characterization of stone monument diseases is the key issue and the essential part of the protection of stone monuments (Wang, 2007). While there has been much research on the extraction of stone monument diseases domestically and internationally, a complete theory has not to be developed and generated. Preventive protection is an important direction in the development of stone monument protection, and the detection and analysis of damage are the most basic and core work of preventive protection (Wang, 2016). Nowadays, some of the techniques and methods of non-destructive testing have been put into practice in the extraction of stone monument diseases (Ji et al., 2020), as well as the initial work of summarizing and generalizing (Zhang, 2017). Nevertheless, it is still hard to meet the needs of stone monument protection regarding the current technology (Li et al., 2021).

In recent years, surveying and mapping technology has been widely used in the protection of monuments, especially in stone monuments protection projects (Rodrigues, 2015). In the relevant regulations, the mapping content and requirements of engineering geology, topography and monuments have been clarified. However, surveying and mapping technology is still a lack of further cognitive and research in the extraction and analysis of stone monument diseases. Therefore, this essay not only combines with the related characteristics of stone monument diseases, and sorts out the application advantages of typical surveying and mapping technology in the extraction and analysis of stone monument diseases, but also makes some beneficial attempts to build the stone monuments protection theory and method system.

\section{ANALYSIS OF DISEASES OF STONE MONUMENTS}

Recently, a few standards and specifications have been issued for stone monument diseases in China (Newell, 2008). However, due to the complex factors of stone monument diseases, the various forms of expression and the scattered distribution (Zhang et al., 2016), thus there are still some problems requiring further improvement. For example, the disease specifications of movable and immovable stone monuments have not been completely unified. It is not clear whether the classification of stone monument diseases based on phenomenon or cause $(\mathrm{Li}$, 2014). And some terms describing the stone monument diseases have yet to be standardized. Nevertheless, the main disease types of stone monuments can still be identified on the basis of the existing research. Based on the "Technical specification for evaluating disease of movable collection - Stone" (State Administration of Cultural Heritage of the People's Republic of China, 2014) and the "Classification and legend on the deterioration of ancient stone objects" (State Administration of Cultural Heritage of the People's Republic of China, 2008) issued by the State Administration of Cultural Heritage of the People's Republic of China, this paper analyses the nature and manifestations of stone monument diseases. It examines the nature and manifestations of stone monument diseases in order to identify the needs of mapping science and technology in the extraction and analysis of stone monument diseases.

According to the "Classification and legend on the deterioration of ancient stone objects", there are seven major categories of stone monument diseases and 21 types of diseases manifestations.

* Corresponding author. E-mail addresses : yz18801430214@126.com (Zheng Yu) 


\begin{tabular}{|c|c|c|c|c|}
\hline $\begin{array}{l}\text { Disease } \\
\text { Category }\end{array}$ & Disease Type & Disease Definition & Disease Character & $\begin{array}{l}\text { Disease } \\
\text { Picture }\end{array}$ \\
\hline \multirow{3}{*}{$\begin{array}{l}\text { Biological } \\
\text { Colonizatio } \\
\mathrm{n} \text { of Stone } \\
\text { Monuments }\end{array}$} & Plant Disease & $\begin{array}{l}\text { Because of plants grow in the cracks of } \\
\text { stone monuments, they destroy the } \\
\text { stone by root cleavage. }\end{array}$ & $\begin{array}{c}\text { Activity Disease } \\
\text { Inducibility Disease }\end{array}$ & \\
\hline & $\begin{array}{l}\text { Animal } \\
\text { Disease }\end{array}$ & $\begin{array}{l}\text { Because of insects, rats and so on, they } \\
\text { build nests, multiply, excrete secretions } \\
\text { or erode stone monuments on the } \\
\text { surface, hollow and cracked part of } \\
\text { stone monuments. }\end{array}$ & $\begin{array}{c}\text { Activity Disease } \\
\text { Inducibility Disease }\end{array}$ & \\
\hline & $\begin{array}{l}\text { Microbial } \\
\text { Disease }\end{array}$ & $\begin{array}{l}\text { Microorganisms grow and multiply on } \\
\text { the surface and cracks of stone } \\
\text { monuments, leading to surface } \\
\text { weathering of stone monuments. }\end{array}$ & $\begin{array}{c}\text { Activity Disease } \\
\text { Inducibility Disease }\end{array}$ & \\
\hline \multirow{2}{*}{$\begin{array}{l}\text { Mechanical } \\
\text { Disruption }\end{array}$} & Disintegration & $\begin{array}{l}\text { Especially refers to a fracture and } \\
\text { dislocation phenomenon with } \\
\text { penetration and obvious displacement. }\end{array}$ & Stability Disease & \\
\hline & Partial Loss & $\begin{array}{l}\text { Partial loss and damage of stone } \\
\text { monuments。 }\end{array}$ & Stability Disease & \\
\hline \multirow{6}{*}{$\begin{array}{c}\text { Surface } \\
\text { Weathering }\end{array}$} & $\begin{array}{c}\text { Surface } \\
\text { Granular } \\
\text { Disintegration }\end{array}$ & $\begin{array}{l}\text { Periodic changes in temperature and } \\
\text { humidity, freeze-thaw, water and salt } \\
\text { activities cause the phenomenon of } \\
\text { surface granular disintegration on the } \\
\text { stone monuments. }\end{array}$ & $\begin{array}{c}\text { Activity Disease } \\
\text { Inducibility Disease }\end{array}$ & \\
\hline & $\begin{array}{l}\text { Surface Salt } \\
\text { Crystal }\end{array}$ & $\begin{array}{c}\text { Due to the activity of capillary water } \\
\text { and soluble salt, soluble salt is enriched } \\
\text { and precipitated on the surface of stone } \\
\text { carving. }\end{array}$ & $\begin{array}{c}\text { Activity Disease } \\
\text { Inducibility Disease }\end{array}$ & \\
\hline & $\begin{array}{l}\text { Surface Flake } \\
\text { Exfoliation }\end{array}$ & $\begin{array}{l}\text { Due to the disturbance of external } \\
\text { force, the destruction of water and salt, } \\
\text { and the change of temperature cycle, } \\
\text { the phenomenon of flake and plate } \\
\text { exfoliation on the surface of stone } \\
\text { monuments is caused. }\end{array}$ & $\begin{array}{c}\text { Activity Disease } \\
\text { Inducibility Disease }\end{array}$ & \\
\hline & $\begin{array}{l}\text { Warp and } \\
\text { Exfoliation in } \\
\text { Scales }\end{array}$ & $\begin{array}{l}\text { Due to the large change in } \\
\text { environmental temperature, the surface } \\
\text { of stone monuments that are prone to } \\
\text { thawing or fire have warped and } \\
\text { exfoliated. }\end{array}$ & $\begin{array}{c}\text { Activity Disease } \\
\text { Inducibility Disease }\end{array}$ & \\
\hline & $\begin{array}{l}\text { Surface } \\
\text { Solution }\end{array}$ & $\begin{array}{l}\text { Stone monuments that have been } \\
\text { washed by rain for a long time, and the } \\
\text { pit or groove shaped dissolution } \\
\text { phenomenon formed on the surface. }\end{array}$ & $\begin{array}{c}\text { Activity Disease } \\
\text { Inducibility Disease }\end{array}$ & \\
\hline & $\begin{array}{l}\text { Cavernous } \\
\text { Weathering }\end{array}$ & $\begin{array}{l}\text { The surface of stone monuments } \\
\text { dissolves and soft inclusions dissolve } \\
\text { with fall off, forming the weathering } \\
\text { phenomenon of holes. }\end{array}$ & $\begin{array}{c}\text { Activity Disease } \\
\text { Inducibility Disease }\end{array}$ & \\
\hline \multirow{2}{*}{$\begin{array}{l}\text { Cracks and } \\
\text { Hollows }\end{array}$} & $\begin{array}{l}\text { Mechanical } \\
\text { Fissure }\end{array}$ & $\begin{array}{l}\text { Cracking phenomenon of stone } \\
\text { monuments caused by external force } \\
\text { disturbance, uneven force, foundation } \\
\text { settlement, stone structure, etc. }\end{array}$ & $\begin{array}{c}\text { Activity Disease } \\
\text { Inducibility Disease }\end{array}$ & \\
\hline & $\begin{array}{l}\text { Superficial } \\
\text { Fissure }\end{array}$ & $\begin{array}{l}\text { Cracks developed along the stone } \\
\text { texture due to natural weathering and } \\
\text { dissolution. }\end{array}$ & $\begin{array}{c}\text { Activity Disease } \\
\text { Inducibility Disease }\end{array}$ & \\
\hline
\end{tabular}




\begin{tabular}{|c|c|c|c|c|}
\hline & $\begin{array}{l}\text { Structural } \\
\text { Fissure }\end{array}$ & Stone itself with structural fissure. & $\begin{array}{c}\text { Activity Disease } \\
\text { Inducibility Disease }\end{array}$ & $\sum_{-200}$ \\
\hline & Hollowing & $\begin{array}{l}\text { The surface layer of the stone } \\
\text { monuments bulges and separates into } \\
\text { cavities, but they are not completely } \\
\text { exfoliation. }\end{array}$ & $\begin{array}{l}\text { Activity Disease } \\
\text { Inducibility Disease }\end{array}$ & \\
\hline \multirow{3}{*}{$\begin{array}{c}\text { Surface } \\
\text { Contaminati } \\
\text { on and } \\
\text { Discoloratio } \\
\text { n }\end{array}$} & $\begin{array}{l}\text { Air and Dust } \\
\text { Pollution }\end{array}$ & $\begin{array}{l}\text { Stone carvings are stored in the open } \\
\text { air. It's surface usually covered with a } \\
\text { lot of dust and weathering products. }\end{array}$ & $\begin{array}{c}\text { Stability Disease } \\
\text { Activity Disease } \\
\text { Inducibility Disease }\end{array}$ & \\
\hline & Rust Crust & $\begin{array}{l}\text { Stone monuments are stored or have } \\
\text { been stored in the open, the crusts } \\
\text { formed on the surface of stone carvings. }\end{array}$ & $\begin{array}{c}\text { Activity Disease } \\
\text { Inducibility Disease }\end{array}$ & \\
\hline & $\begin{array}{l}\text { Human } \\
\text { Pollution }\end{array}$ & $\begin{array}{l}\text { Contamination of stone monuments } \\
\text { caused by graffiti, writing and soot. }\end{array}$ & $\begin{array}{c}\text { Stability Disease } \\
\text { Activity Disease } \\
\text { Inducibility Disease }\end{array}$ & \\
\hline \multirow{2}{*}{$\begin{array}{l}\text { Painted } \\
\text { Stone } \\
\text { Surface } \\
\text { Pigment } \\
\text { Disease }\end{array}$} & $\begin{array}{c}\text { Surface } \\
\text { Pigment Loss }\end{array}$ & $\begin{array}{l}\text { The pigment cementation of the painted } \\
\text { stone carving layer is aging, which } \\
\text { leads to the loss of the color paint. }\end{array}$ & $\begin{array}{c}\text { Activity Disease } \\
\text { Inducibility Disease }\end{array}$ & \multirow{2}{*}{ (i) 3 - 3 . } \\
\hline & $\begin{array}{c}\text { Surface } \\
\text { Pigment Crisp } \\
\text { Powder }\end{array}$ & $\begin{array}{c}\text { The pigment cementation of the painted } \\
\text { stone carving layer is aging, which } \\
\text { leads to the crisp powder of the color } \\
\text { paint. }\end{array}$ & $\begin{array}{c}\text { Activity Disease } \\
\text { Inducibility Disease }\end{array}$ & \\
\hline $\begin{array}{l}\text { Cement } \\
\text { Repair }\end{array}$ & $\begin{array}{l}\text { Cement } \\
\text { Repair }\end{array}$ & $\begin{array}{l}\text { Use cement materials to bond, } \\
\text { reinforce, repair and other changes to } \\
\text { the original appearance of monuments. }\end{array}$ & $\begin{array}{c}\text { Stability Disease } \\
\text { Activity Disease } \\
\text { Inducibility Disease }\end{array}$ & insents \\
\hline
\end{tabular}

Table 1 Classification and definition of stone monuments diseases

In addition, in "Technical specification for evaluating disease of movable collection - Stone", the corresponding measurement items required for various stone monument diseases are also specified in detail.

\begin{tabular}{|c|c|c|c|c|c|}
\hline & \multicolumn{5}{|c|}{ Measuring Project } \\
\hline Disease Name & $\begin{array}{c}\text { Diseases } \\
\text { Number }\end{array}$ & $\begin{array}{c}\text { Disease } \\
\text { Length }\end{array}$ & Disease Area & Disease Depth & $\begin{array}{c}\text { Disease } \\
\text { Volume }\end{array}$ \\
\hline Disintegration & $\sqrt{ }$ & & & & $\sqrt{ }$ \\
\hline Loss & $\sqrt{ }$ & & & $\sqrt{ }$ & \\
\hline crack & $\sqrt{ }$ & $\sqrt{ }$ & $\sqrt{ }$ & \\
\hline Hollowing & $\sqrt{ }$ & & $\sqrt{ }$ & & \\
\hline Hole & $\sqrt{ }$ & & $\sqrt{ }$ & & \\
\hline Surface Solution & $\sqrt{ }$ & & $\sqrt{ }$ & & \\
\hline Surface Granular & $\sqrt{ }$ & & $\sqrt{ }$ & \\
\hline Surface Salt Crystal & $\sqrt{ }$ & & $\sqrt{ }$ & \\
\hline Flake Exfoliation & $\sqrt{ }$ & & $\sqrt{ }$ & \\
\hline Warp & $\sqrt{ }$ & & $\sqrt{ }$ & \\
\hline Rust Crust & $\sqrt{ }$ & & $\sqrt{ }$ & & \\
\hline Surface & $\sqrt{ }$ & & $\sqrt{ }$ & & \\
\hline Contamination & $\sqrt{ }$ & & $\sqrt{ }$ & \\
\hline Plant Disease & $\sqrt{ }$ & & & & \\
\hline Animal Disease & $\sqrt{ }$ & & & \\
\hline Microbial Disease & $\sqrt{ }$ & & & \\
\hline Surface Pigment & $\sqrt{ }$ & & & \\
\hline
\end{tabular}




\begin{tabular}{|c|l|l|l|l|l|}
\hline Loss & & & & & \\
\hline $\begin{array}{c}\text { Surface Pigment } \\
\text { Crisp Powder }\end{array}$ & $\sqrt{ }$ & & $\sqrt{ }$ & & \\
\hline
\end{tabular}

Table 2 Stone monument disease survey project

\section{ANALYSIS OF THE RESEARCH STATUS OF STONE MONUMENT DISEASES BY KEY TECHNOLOGY OF SURVEYING AND MAPPING}

Surveying and mapping technology is a technology for acquiring spatial information based on information science, spatial science, and computer technology, with GIS, RS and GNSS technology as the core (Liu, 2020). It can be used of measuring, mapping, and modelling the size, shape, and spatial location relationships of natural geographical elements. Recently, surveying and mapping technologies represented by 3D laser scanning (Thamir, Abed, 2020), close-range photogrammetry (Hou, Bu, 2019), UAV oblique photogrammetry (Molnar, 2018), multi/hyperspectral (Cerra et al., 2018) and industrial cameras (Guo, 2017) have developed rapidly. By the characteristics of non-destructive and high-precision, it is gradually being applied to the detection, extraction, and analysis of stone monument diseases.

\subsection{D Laser Scanning}

3D laser scanning technology as a high tech is another technological revolution after GPS in surveying and mapping field. This technology obtains the three-dimensional information of the object's surface measured up to submillimeter accuracy by the method of high-speed laser scanning measurement. Wang Hao and his team have measured the stone structural plane, crack distribution, occurrence, spacing and other information of Thousand-Buddha cliff inscription and obtained the point cloud data of with the overall point accuracy $<2 \mathrm{~mm}$,texture point accuracy $<1 \mathrm{~mm}$ though $3 \mathrm{D}$ laser scanning technology (Wang et al., 2016). He Yong has built three-dimensional information digital archive about Yungang Grottoes through 3D laser scanning technology and close-range photogrammetry with accuracy less than $3 \mathrm{~mm}$ error (He, 2016). Peng Yong and his team have completed relic model's features that error less than $1 \mathrm{~mm}$ through 3D leaser scanning technology (Peng et al., 2016). B. Davidde Petriaggi and his team have confirmed that 3D leaser scanning technology is available under the water, also have built models and obtains the surface of relief's information up to submillimeter accuracy (Petriaggi, Ayala, 2015). Jiang Xiaoxi and his team have given an analysis method based on 3D Leaser scanning technology and numerical simulation technology about the rock pillar monuments with complex shape (Jiang et al., 2016). Shi Junli has calculated the Cave 11 of Yungang Grottoes' three-dimensional model through 3D leaser scanning technology, also have analyzed the change about the spatial displacement and the stability about the structure (Shi, 2015). Wu Yuhua and his team have saved the three-dimensional information about the Thousand-Buddha cliff inscription and have recovered it in digital through the hyperfine 3D laser scanning technology, also they have applied this technology can be used in tracking the protection of the monuments (Wu et al., 2011).

\subsection{Photogrammetry}

Photogrammetry is the method of using optical photographs to achieve rapid acquisition and accurate collection of multi-angle textural features and high-precision three-dimensional information. Huang Shan and his team drew more than 252 grottos and Maiji mountain are drew 33 grottos based on Multi-
Baseline Close-range Photogrammetry (Huang et al., 2016). C. Alyilmaz and his team have completed the feature extraction and morphological analysis of the surface patterns of Qubostan's rock paintings (Alyilmaza et al., 2010). Yu Bingchen and his team have presented a way to rebuild unmovable monuments in high-precision, the accuracy can reach $0.5 \mathrm{~mm}$ (Yu et al., 2017). Chen Gang and his team have measured surface of the Stone Sculptures along the Spirit Roads of Tombs of the Southern Dynasties Period through UAV (Chen et al., 2017). Song has separated the details and built the model of the monuments through the industrial camera. The experimental results show the accuracy of it is $0.1 \mathrm{~mm}$ (Song et al., 2018). Hua Wei and his team have presented a method named "partition block"to extract information about the wall painting. It can correct the distortion of the wall painting, and restore the original color information of the wall painting (Hua et al., 2017). Xia Guofang and his team have obtained colors and structures' information of the monuments' surface through Photogrammetry technology and 3D leaser scanning technology. They also have completed the detection and measurement the surface of monument's diseases through geometry, texture information collaborative feedback mechanism (Xia et al., 2018a). In the same year they have built high-fidelity colorful model through image transparent point mapping and 3D leaser scanning technology, which can be used for irregular monuments' information collection and 3D monitoring works (Xia et al., 2018b).

\subsection{Hyperspectral Remote Sensing}

Hyperspectral Remote Sensing is a method of data collecting combines spatial and spectral features, which is due to have "integration of atlas" feature and concern. Ma Wenwu and his team have proposed a minimum noise fraction change method based on the threshold, and combine it with the hyperspectral technology to extract and analysis stone tablets' characteristic information and raw material composition (Ma et al., 2015). Zhou Xiao and his team have used hyperspectral imaging to analysis Yungang Grottoes' weathering condition, after normalized they can visualize the distribution of weathering diseases (Zhou et al., 2012). Sun Meijun and her group have collected different stages information of flaking of the murals disease to build a spectral library, also have used the PLSR assessment model realized the risk assessment of the flaking (Sun et al., 2016).

\subsection{Thermal Infrared Imaging}

Infrared imaging technology is a technical method for transform infrared radiation into a "thermal image". It has great effect for detection of the seepage in stone monuments diseases. Zhang Huihui have extracted image changes of rocks with different humidity under the lighting condition through infrared imaging technology, and proposed a thought to extract the thermal difference of the water-bearing property of rocks by differences (Zhang, 2013). Wu Yuhua and his mates have explored application of thermal infrared image technology in detecting cliff paintings encrustation, spalling and seepage diseases, also analysis the benefits of this technology (Wu, Liu, 2010a). In the same year, this team used the same technology to detect the seepage area, judgement of seepage quantity and division degree 
of seepage are of Huashan rock paintings, which is located in Guangxi province (Wu, Liu, 2010b).

\subsection{Analysis of The Advantages of Surveying and Mapping Technology}

After analysis of the research above, surveying and mapping technology has been initially applied in the protection of cultural stone monuments. It also has obvious advantages in extracting the information in quantity, length, are and volume of cultural stone monuments. 3D laser scanning technology and close-range photogrammetry technology can provide substantial information of the disease's characteristic of cultural stone monuments in a non-contact situation accurate acquisition and built fine threedimensional model, and these technologies have remarkable effect on detecting the shape and color change of the disease of the cultural stone monuments. Hyperspectral remote sensing technology can obtain both image information and component information, it can provide reliable proof for qualitative and quantitative analysis diseases of cultural stone monument. Thermal infrared imaging technology is an important way to detect the internal disease information of cultural stone monuments, and it has great achievements in the structural analysis of cultural stone monuments and the detection of floods. Beside distinguishing features such as high surveying accuracy, high automatic extent, and strong adaptability, another significant advantage is non-contact, through this method without contact with the cultural stone monuments, the damage to the cultural stone monuments can be minimized, and the safety of the cultural stone monuments can be ensured. At the same time, surveying, and mapping technology as an effective way to obtain the noumenon of cultural stone monuments and the surrounding environmental information, can be used to provide basic support for the identification and quantify disease of the cultural stone monument. In addition, the achievements of surveying and mapping technology in various forms of expression, it can clearly reflect the spatial distribution and three-dimensional characteristics of cultural stone monuments diseases, it is convenient to analysis and comprehensive to exhibit.

\section{THE PROSPECT OF SURVEYING AND MAPPING USING IN STONE MONUMENTS PROTECTION}

In recent years, driven by emerging information technologies such as cloud computing (Cavalcante et al., 2016), digital twinsand (Uhlemann et al., 2017), artificial intelligence (Dong et al., 2021), surveying and mapping technology is gradually moving from numeralization to intellignetize. In order to meet the demand of stone monuments protection, surveying and mapping technology is necessary to conduct further research.

\subsection{Define the applicability of surveying and mapping technology}

Compared with other technologies, surveying and mapping technology in the field of cultural stone monuments protection in China is relatively late. In addition, there are many kinds of diseases of cultural stone monuments in China, and the representation is complex, and there is no clear classification standard, therefore, there are some problems in the way of how to detect the diseases. So, the feasibility of clear and definite surveying and mapping technology in the detection of cultural stone monuments disease, and clarify the relationship between various diseases and different mapping techniques, it is helpful to build up advantage of surveying and mapping technology in the cultural stone monuments protection.

\subsection{Realization of intelligent data acquisition}

Intelligent data acquisition is not only the development needs nowadays, but also the inevitable trend of surveying and mapping technology development. Compared with traditional surveying and mapping technology, measuring robot (Palaniappan et al., 2011), intelligent scanner (Scherer, 2005) and UAV and other intelligent mapping equipment have higher work efficiency and stronger environmental adaptability. Combined with cloud computing and other related technologies, it is expected to build an intelligent data acquisition system that can cover protection of the cultural stone monuments industry.

\subsection{Build up a monitoring system of diseases}

Diseases' monitoring system is an important link in the protection of cultural stone monuments. We can realize the prediction of disease development trend after analysis the data changes of the diseases about the cultural stone monuments. So far, surveying and mapping technology is used in environmental monitoring, ontology monitoring and performance monitoring, if we analyze it with the cultural stone monuments disease, which can help to realize the evaluation of diseases, and to realize a foundation of preventive protection.

\section{CONCLUSION}

As mentioned above, the protection of cultural stone monuments in China started relatively late. There are still some problems such as classification of diseases accurately, classification of diseases and accurate extraction. To realize the scientific protection of cultural stone monuments and the rational analysis of diseases, we still need to discuss the choice of detection methods and the solution of monitoring system.

Today, surveying and mapping technology is closely integrated with the protection of cultural stone monuments, it is helpful to use surveying and mapping technology to realize information extraction and digital protection of cultural stone monuments. The author thinks that the technology of surveying and mapping has a good prospect, combined with the emerging information technology, it plays a significant role in the identification, extraction, evaluation, and monitoring of the disease of cultural stone monuments, also to realize a foundation of preventive protection about the cultural stone monument.

\section{ACKNOWLEDGEMENTS}

The author will thank National Key R\&D Program of China (NO 2019YFC1520804) and Youth Beijing Scholar Program.

\section{REFERENCES}

Huang, K.Z., 2006. Current situation and trend of scientific and technological protection of cultural relics in China. China Cultural Heritage Scientific Research, 2006(01), 75-79.

Plevoets, B., Van Cleempoel, K. 2011. Adaptive reuse as a strategy towards conservation of cultural heritage: a literature review. Structural studies, repairs and maintenance of heritage architecture XII, 118(12), 155-163.

Maev, R. G., Baradarani, A., Taylor, J. R. B. 2020. New concept for art and antiquities identification based on craquelure pattern analysis. Insight-Non-Destructive Testing and Condition Monitoring, 62(3), 134-138. doi:10.1784/insi.2020.62.3.134. 
Wang, J.H., Huo, X.T., 2021. A Discussion on the Key Scientific and Technological Issues in Cave Temples Protection. Southeast Culture, 2021(01), 6-13.

De Wever, P., Baudin, F., Pereira, D., Cornée, A., Egoroff, G., Page, K. 2017. The importance of geosites and heritage stones in cities-A review. Geoheritage, 9(4), 561-575. doi:10.1007/s12371-016-0210-3.

Huang, K.Z., 2014. See the influence of Venice Charter from the course of stone cultural relics protection in our country. China Cultural Heritage Scientific Research, 2014(02), 12-14.

Wang, J.H., 2007. A special study on preservation status and disease of Dazu Thousand-hand Guanyin statue. China Cultural Heritage Scientific Research, 2007(02), 70-78. doi:10.3969/j.issn.1674-9677.2007.02.017.

Wang, D.H., 2016. Study on anchoring performance and mechanism of modified glutinous rice mortar and SH mixed grout bolt in soil ruins. Lanzhou University of Technology. doi:10.7666/d.D01027823.

Ji, J., Wang, Y.J., Ma, T., Wang, J., Dong, S.H., Zhou, W.Q., 2020. Analytical study of contaminants and soluble salts on the surface of stone sculptures at Mao Mausoleum,Shaanxi. Sciences of Conservation and Archaeology, 32(02), 22-28.

Zhang, B.F., 2017: Introduction to grottoes protection technology. Heritage Press, Beijing.

Li, A.Q., Zhou, K.P., Xie, L.L., Wang, C.C., Yong, X.Q., 2021. Rethinking the preventive protection of Chinese architectural heritage. China Cultural Heritage, 2021(01), 13-22.

Rodrigues, J. D., 2015. Defining, mapping and assessing deterioration patterns in stone conservation projects. Journal of Cultural Heritage, 16(3), 267-275. doi:10.1016/j.culher.2014.06.007.

Newell, P., 2008. The PRC's Law for the Protection of Cultural Relics. Art Antiquity \& L. 13, 1.doi: 10.2337/dc09-0116.

Zhang, T., Li, D.Q., Zhang, Z.J., 2016. Damage categories and deterioration mechanism of stone cultural relics of white marble in Beijing. Geotechnical Investigation \& Surveying, 2016,44(11), 7-13.

Li, H.S., 2014: Degradation characteristics and evaluation methods of rock materials of stone cultural relics. Heritage Press, Beijing.

State Administration of Cultural Heritage of the People's Republic of China, 2014: Technical specification for evaluating disease of movable collection - Stone : WW/T 0062-2014. Heritage Press,Beijing.

State Administration of Cultural Heritage of the People's Republic of China, 2008: Classification and legend on the deterioration of ancient stone objects : WW/T 0002-2007. Heritage Press, Beijing.

Liu, Z.M., 2020. Survey on the development trend and expansion of surveying and mapping specialty under the new situation. Regional Governance,2020(04), 112-114.
Thamir, Z. S., Abed, F. M., 2020. How geometric reverse engineering techniques can conserve our heritage; a case study in Iraq using 3D laser scanning. In IOP Conference Series: Materials Science and Engineering (Vol. 737, No. 1, p. 012231). IOP Publishing. doi: 10.1088/1757-899X/737/1/012231.

Hou, G.D., Bu, C.G., 2019. Application of digital close-up photogrammetry in archeology. Geomatics Technology and Equipment, 21(04), 82-85+81.

Molnar, A., 2018. 3D reconstruction of monuments from drone photographs based on the spatial reconstruction of the photogrammetric method. Adv. Sci. Technol. Eng. Syst. J, 3, 252-258. doi:10.25046/aj030633.

Cerra, D., Agapiou, A., Cavalli, R. M., Sarris, A., 2018. An objective assessment of hyperspectral indicators for the detection of buried archaeological relics. Remote Sensing, 10(4), 500. doi:10.3390/rs10040500.

Guo,H., 2017. Research on crack monitoring system of concrete dam based on machine vision. Dalian University of Technology, 2017.

Wang, H., Li, Z.J., Wang, S., Li, Y.S., 2016. 3D laser scanning application of joint measuring in the cliff stone geological survey. Engineering Geology Committee of Geological Society of China Proceedings of 2016 National Engineering Geology Academic Annual Meeting. Engineering Geology Committee of Geological Society of China: Editorial Department of Journal of Engineering Geology, 215-219.

He, Y., 2016. Digital exploration of large high relief stone relics -- taking Yungang Grottoes as an example. China Cultural Heritage, 2016(02), 30-33.

Peng, Y., Yao, X.W., Hu, Y.J., 2016. The Application Research of 3D Laser Scanning technology on Rocky Historical Relics Conservation. Urban Geotechnical Investigation \& Surveying, 2016(03), 97-100.

Petriaggi, B. D., Ayala, G. G., 2015. Laser scanner reliefs of selected archeological structures in the submerged Baiae (Naples). The International Archives of Photogrammetry, Remote Sensing and Spatial Information Sciences, 40(5), 79. doi: 10.5194/isprsarchives-XL-5-W5-79-2015.

Jiang, X.X., Wu, Q., Deng, X.L., Wang, X.L., Li, L.H., 2016. Disease investing of rock pillar cultural relics with complex shape and prevention measures - taking KeyanYungu rock pillar in Zhejiang Province as example. Geotechnical Investigation \& Surveying, 44(10), 1-5.

Shi, J.L., 2015. Application of three-dimensional laser scanning technology in historic stone's numerical simulation. Journal of Light Industry, 30(Z2), 70-75.

Wu, Y.H., Wang, J.H., Hou, M.L., Zhang, Y.M., 2011. The application of 3-D laser scanning to the conservation of stone cultural relics. Sciences of Conservation and Archaeology, 23(04), 104-110. doi:10.16334/j.cnki.cn31-1652/k.2011.04.001.

Huang, S., Zhang, Z.X., Ke, T., Zhang, J.Q., Wu, B.C., 2016. Archaeological mapping of grottoes based on multi-baseline close-range photogrammetry. Dazu Journal, 2016, 231-242. 
Alyilmaza, C., Alyilmaza, S., Yakarb, M., 2010. Measurement of petroglyhps (rock of arts) of Qobustan with close range photogrammetry. International Archives of Photogrammetry, Remote Sensing and Spatial Information Sciences, 38(5), 29-32.

Yu, B.C., Chen, G., Duan, M.R., Cao, F.F., Zhang, X., 2017. UAV RS Applied in 3D Reconstruction of Huge Immovable Cultural Relics. Bulletin of Surveying and Mapping, 2017(05), 43-46+61. doi:10.13474/j.cnki.11-2246.2017.0151.

Chen, G., Duan, M.R., Yu, B.C., 2017. The digital study of the tomb stone carvings of six dynasties in Nanjing based on the UAV remote sensing technology: a case study of the 3D modeling of the stone carvings at Shizichong. Studies on Ancient Capitals in China , 2017(32), 12.

Song L., Li X., Yang Y., 2018. Structured-light based 3D reconstruction system for cultural relic packaging. Sensors, 18(9), 2981. doi:10.3390/s18092981.

Hua W., Yungang H U., Hou M., 2017Study on the Partition Block Method of Mural Photograph Collection. Geomatics World. doi:10.3969/j.issn.1672-1586.2017.03.021.

Xia, G.F., Hu, C.M., Wang, Y.M., 2018a. Study on true threedimensional detection method of cultural relic surface diseases. China Cultural Heritage Scientific Research, 2018(01),89-96.

Xia, G.F., Hu, C.M., Fan, L., 2018b. A Method for Reconstructing Precise 3D Models for Statues. Dunhuang Research, 2018(03), 131-140.

Ma, W.W., Hou, M.L., Hu, Y.G., 2015. Stone Feature Information Extraction Based on Hyper-Spectral Remote Sensing. Journal of Beijing University of Civil Engineering and Architecture, 31(02), 65-69.

Zhou, X., Gao, F., Zhang, A.W., Zhou, K.C., 2012. Advance in the Study of the Powdered Weathering Profile of Sandstone on China Yungang Grottoes Based on VIS/NIR Hyperspectral Imaging. Spectroscopy and Spectral Analysis, 32(03), 790-794. doi: 10.3964/j.issn.1000-0593(2012)03-0790-05.

Sun, M.J., Chai, B.L., Zhang, D., Wang, Z., Sun, J.Z., 2016. Assessing the degree of flaking of the murals in the Dunhuang Mogao Grottoes using near-infrared hyperspectral imaging. Sciences of Conservation and Archaeology, 28(04), 1-8.

Zhang, H.H., The Experimental Study on the Use of Infrared Thermal Imaging for Nondestructive Detection of Deterioration Disease in Stone Relics. Journal of Liaoning Provincial College of Communications, 15(06), 20-22.

Wu Y., Liu S., 2010a. Infrared imaging detection on waterpermeation of rock paintings. Geotechnical Investigation \& Surveying, 38(5), 31-35. doi:10.3724/SP.J.1231.2010.06586. doi: 10.3724/SP.J.1231.2010.06586.

Wu, Y.H., Liu, S.J., 2010b. Exploration of the use of infrared thermal imaging technology for detection of deterioration in rock paintings. Sciences of Conservation and Archaeology, 22(02), 12-17.

Cavalcante, E., Pereira, J., Alves, M. P., Maia, P., Moura, R., Batista, T., Pires, P. F. 2016. On the interplay of Internet of Things and Cloud Computing: A systematic mapping study.
Computer Communications, 89, 17-33. doi: 10.1016/j.comcom.2016.03.012.

Uhlemann, T. H. J., Schock, C., Lehmann, C., Freiberger, S., Steinhilper, R. 2017. The digital twin: Demonstrating the potential of real time data acquisition in production systems. Procedia Manufacturing, 9, 113-120. doi: 10.1016/j.promfg.2017.04.043.

Dong, W., Gong, Q., Yuan, K., 2021. Application of Artificial Intelligence-Based UAV Photogrammetry Technology in Electric Power Surveying and Mapping Engineering. doi:10.1007/978-981-33-4572-0_163.

Palaniappan, R., Mirowski, P., Ho, T. K., Steck, H., Whiting, P., MacDonald, M., 2011. Autonomous RF surveying robot for indoor localization and tracking. In International conference on indoor positioning and indoor navigation.

Scherer, M., 2005. Photo Tacheometry and Intelligent Scanning. An Alternative to 3D-Laser Scanning. In Proceedings of the XX International Symposium, CIPA. 